\title{
Effect of Ukrain on matrix metalloproteinase-2 and Secreted Protein Acidic and Rich in Cysteine (SPARC) expression in human glioblastoma cells Nicoletta Gagliano ${ }^{a}$, Claudia Moscheni ${ }^{a}$, Carlo Torri ${ }^{a}$, Ivana Magnani ${ }^{b}$, Alberto A.E. Bertelli ${ }^{a}$, Wassil Nowicky ${ }^{\mathrm{c}}$ and Magda Gioia ${ }^{\mathrm{a}}$
}

\begin{abstract}
Glioblastoma is a highly malignant brain tumor with a highly invasive phenotype and hence an unfavorable prognosis even in response to multidisciplinary treatment strategies. Ukrain, a semi-synthetic thiophosphoric acid derivative of the purified alkaloid chelidonine, has been used in the therapy of several solid tumors, but little is known about its effect on glioblastoma and, in general, about the molecular mechanisms responsible for its effects. We used RT-PCR, Western blot and SDSzymography to investigate the effects of three doses of Ukrain $(0.1,1$ and $10 \mu \mathrm{mol} / \mathrm{l})$ on the expression of genes and proteins involved in the extracellular matrix remodeling associated with tumor invasion in human cultured glioblastoma cells treated for 24,48 and $72 \mathrm{~h}$. We analyzed the expression of matrix metalloproteinase-2 and -9 , the main mediators of glioblastoma invasiveness, and secreted protein acidic and rich in cysteine (SPARC), involved in the regulation of cell-matrix interactions. There was a significant, dose-related decrease of glioblastoma cell
\end{abstract}

\section{Introduction}

Ukrain (NSC 631570) is purified water-soluble alkaloids isolated from greater celandine (Chelidonium majus L.), a member of the Papaveracee family [1]. It is employed as an anti-cancer agent, with high cytotoxic activity on malignant cells $[2,3]$. Ukrain is also an immunostimulating and immunomodulating compound [4], and has antiangiogenic effects on human endothelial cells in vitro [5].

Over the past years plant extracts such as Ukrain have been investigated as new anti-tumoral drugs in the search for therapeutic strategies for malignancies. Ukrain acts both as a single agent and in combination with conventional chemotherapy, and there are case reports of responses for a range of solid tumors including the colon, rectum, breast, pancreas, bladder and ovary [6-10]. To our knowledge, however, little information is available on the treatment of brain tumors such as gliomas.

Among brain tumors, one of the leading causes of death among young children and adults, gliomas are the most common primary brain malignancies, accounting for more than $40 \%$ of all central nervous system neoplasms [11], and glioblastoma is a highly malignant glioma typically affecting adults between 45 and 60 years of age [12]. proliferation and a tendency to downregulation of SPARC at the protein level $72 \mathrm{~h}$ after $10 \mu \mathrm{mol} / \mathrm{I}$ Ukrain, suggesting the drug may be a useful therapeutic tool for brain tumors. Anti-Cancer Drugs 17:189-194 (c) 2006 Lippincott Williams \& Wilkins.

Anti-Cancer Drugs 2006, 17:189-194

Keywords: glioblastoma, matrix metalloproteinase, secreted protein acidic and rich in cysteine, Ukrain

Departments of ${ }^{a}$ Human Morphology-LITA Segrate, ${ }^{b}$ Biology and Genetics, University of Milan, Milan, Italy and ' ${ }^{C}$ krainian Anti-Cancer Institute, Vienna, Austria.

Correspondence to N. Gagliano, University of Milan, Department of Human Morphology, Via Fratelli Cervi 93, Segrate, 20090 Milan, Italy. Tel: + 3902 50330462; fax: + 390250330452 ; e-mail: nicoletta.gagliano@unimi.it

Received 15 September 2005 Accepted 14 October 2005

With its highly invasive phenotype, glioblastoma infiltrates diffusely into regions of the normal brain, making total surgical removal impossible; therefore, patients have a poor prognosis, even in response to multidisciplinary treatment strategies including surgery, radiotherapy and chemotherapy $[13,14]$.

The physical processes of tumor invasion, that involve disengagement of the cells from their microenvironment, followed by breakdown of the surrounding matrix, cell movement and re-establishment of the local environment at a new site, enable glioblastoma cells at the tumorinvasive front to overcome the extracellular matrix (EGM) barrier and penetrate adjacent brain structures. This is accomplished by an ECM remodeling process involving matrix metalloproteinases (MMPs) and secreted protein acidic and rich in cysteine (SPARC) [15-17].

MMPs are a family of zinc-dependent, tumor cellsecreted proteolytic enzymes that break down ECM components $[18,19]$. Their expression in gliomas correlates the tumor invasiveness with the proteolytic activity of MMP [20-22]. Gelatinases, particularly MMP-2 and -9, can be considered the prime factor in glioma invasiveness, 
since they break down the basement membrane ECM components, such as collagen type IV and laminin. MMP2 and -9 expression also correlates with the progression and the degree of malignancy of gliomas [23,24].

SPARC is an important multifunctional glycoprotein that influences a number of biological processes, including cell differentiation, migration and proliferation, modulating cellular interactions with ECM. In particular, SPARC regulates focal cell adhesion and cell-matrix interactions, binding to structural matrix proteins, such as collagens and vitronectin. Since in the mechanisms leading to tumor invasion the ability of the tumor cell to migrate and invade the surrounding environment is dependent on the modulation of the interactions between tumor cells with ECM components, SPARC may have a functional role during tumor cell invasion into adjacent brain tissue.

With its counter-adhesive properties, SPARC affects cellmatrix interactions [25-27] and therefore may well have a functional role in tumor cell invasion of adjacent brain tissue. SPARC is also involved in proteolytic pathways by increasing the expression of collagenase and MMP-9, and activating MMP-2 [28]. This protein is frequently overexpressed in gliomas, and its expression correlates with glioma invasion in vitro and in vivo [29-31]. SPARC may be a marker of invading cells.

In this study we analyzed the effect of Ukrain on human cultured glioblastoma cells to investigate whether it affected cell proliferation, and the expression of genes and proteins involved in the mechanisms leading to tumor invasion.

\section{Materials and methods Cell cultures}

Three human glioblastoma MI cell lines (T60, T63, GBM) were obtained from biopsy specimens, as described elsewhere [32]. Cell lines were maintained by serial passages in RPMI 1640 medium containing $10 \%$ heat-inactivated $\mathrm{FBS}$ at $37^{\circ} \mathrm{C}$ in a $5 \% \mathrm{CO}_{2}$ atmosphere and were used within the first 20 passages. Glioblastoma cells (grade IV glioma cells) were cultured in RPMI supplemented with $10 \%$ FBS and $10 \mathrm{U} / \mathrm{ml}$ penicillin plus $10 \mathrm{mg} / \mathrm{ml}$ streptomycin at $37^{\circ} \mathrm{C}$ in a humidified atmosphere containing $5 \% \mathrm{CO}_{2}$.

\section{Drug preparation}

Ukrain (Nowicky Pharma, Vienna, Austria) was obtained as a 5-mg C. majus L. alkaloid thiophosphoric acid derivative plus triethylene-thiophosphoric acid triamide (Thio-TEPA) $/ 5 \mathrm{ml} \mathrm{H}_{2} \mathrm{O}$. According to the manufacturer's instructions, the stock solution was stored at room temperature. Working solutions contained $0.1,1$ and $10 \mu \mathrm{mol} / \mathrm{l} \mathrm{Ukrain}$.

\section{Ukrain treatment}

Glioblastoma cells were initially treated with different doses of Ukrain $(0.1-100 \mu \mathrm{mol} / \mathrm{l})$ to establish the highest dose for cell treatment that had no cytotoxic effect. Glioblastoma cells were then treated with three final concentrations of Ukrain $(0.1,1$ and $10 \mu \mathrm{mol} / \mathrm{l})$. Untreated cultures served as controls. Controls and treated cells were incubated for 24, 48 and $72 \mathrm{~h}$. Each cell line was cultured in duplicate. Glioblastoma cell viability was determined by Trypan blue staining.

\section{RT-PCR analysis}

Total RNA was extracted by a modification of the guanidine isothiocyanate/phenol/chloroform method (TriReagent; Sigma, St Louis, Missouri, USA). After DNase I digestion, $1 \mu \mathrm{g}$ of total RNA was reverse transcribed in $20 \mu \mathrm{l}$ final volume of reaction mix (Promega, Milan, Italy). The following primers were used: GAPDH 5'-ATTCCATGGCACGGTCAAGGCT, 3'-TCAGGTCCACCACGACACGTT (571 bp); MMP-2 5'-CCTCTCCACTGCGTTCGATACACG, 3 '-AGCATCTATTCTTGGGCACGG (162 bp); SPARC 5-ACCATGAGGGCGTGGATC, 3'-GGAGTGGATTTAGATCACAAG (936 bp).

Amplification reactions were conducted in a final volume of $25 \mu \mathrm{l}$ containing $2.5 \mu \mathrm{l}$ of cDNA, $200 \mu \mathrm{mol} / \mathrm{l}$ of the four dNTPs, 100 pmol of each primer, and $2.5 \mathrm{U}$ of Taq DNA polymerase (EuroTaq; Euroclone, Pero, Milan, Italy). The RT-PCR protocols are listed in Table 1. The RT-PCR products were resolved by electrophoresis in $1.5 \%$ agarose gels, stained with ethidium bromide and quantified in duplicate by densitometric analysis (Image Pro-Plus). Changes in mRNA levels are expressed as normalized optical densities relative to GAPDH mRNA.

\section{SDS-zymography}

Pro-MMP-2 and -9 protein levels were measured by SDSzymography in the supernatants of cultured glioblastoma cells. Supernatants were concentrated in an Amicon Y10 at $6500 \mathrm{~g}$ for $15 \mathrm{~min}$ at $4^{\circ} \mathrm{C}$. The concentrated culture media were mixed 3:1 with sample buffer containing $10 \%$ SDS; $60 \mu \mathrm{g}$ total protein per sample was run under non-reducing/non-denaturing conditions (with SDS, but without heat denaturation of samples) onto $7.5 \%$

Table 1 RT-PCR amplification conditions

\begin{tabular}{lcc}
\hline Gene & Protocol & No. cycles \\
\hline MMP-2 & $\begin{array}{c}\text { denaturation } 94^{\circ} \mathrm{C} 1 \mathrm{~min} ; \\
\text { annealing } 60^{\circ} \mathrm{C} 2 \mathrm{~min} ; \\
\text { elongation } 72^{\circ} \mathrm{C} 3 \mathrm{~min} \\
\text { denaturation } 94^{\circ} \mathrm{C} 1 \mathrm{~min} ; \\
\text { annealing } 55^{\circ} \mathrm{C} 1 \mathrm{~min} ; \\
\text { elongation } 72^{\circ} \mathrm{C} 1 \mathrm{~min} \\
\text { denaturation } 94^{\circ} \mathrm{C} 30 \mathrm{~s} ; \\
\text { annealing } 62^{\circ} \mathrm{C} 1 \mathrm{~min} ; \\
\text { elongation } 72^{\circ} \mathrm{C}\end{array}$ \\
$\begin{array}{l}1 \text { min }+72^{\circ} \mathrm{C} 10 \mathrm{~min} \text { to } \\
\text { finalize extension }\end{array}$ \\
\hline
\end{tabular}


polyacrylamide gel SDS-PAGE co-polymerized with $1 \mathrm{mg} / \mathrm{ml}$ type I gelatin. The gels were run at $4^{\circ} \mathrm{C}$. After SDS-PAGE, the gels were washed twice in $2.5 \%$ Triton $\mathrm{X}-100$ for $30 \mathrm{~min}$ each, and incubated overnight in a substrate buffer at $37^{\circ} \mathrm{C}$ Tris- $\mathrm{HCl} 50 \mathrm{mmol} / \mathrm{l}, \mathrm{CaCl}_{2}$ $5 \mathrm{mmol} / \mathrm{l}$ and $\mathrm{NaN}_{3} 0.02 \%$, pH 7.5. After staining the gels with Coomassie brilliant blue R250, the MMP gelatinolytic activity was detected as clear bands on a blue background [33]. To confirm the identity of MMP gelatinolytic activity, purified MMP-1 and -2 (100 ng; Calbiochem, San Diego, California, USA) were run as controls.

\section{Western blot}

Concentrated culture media ( $20 \mu \mathrm{g}$ of total proteins) were diluted in SDS-sample buffer, loaded on $10 \%$ SDSpolyacrylamide gel, separated under reducing and denaturing conditions at $80 \mathrm{~V}$ according to Laemmli [34], and transferred at $90 \mathrm{~V}$ to a nitrocellulose membrane in $0.025 \mathrm{~mol} / \mathrm{l}$ Tris, $192 \mathrm{mmol} / \mathrm{l}$ glycine and $20 \%$ methanol, pH 8.3 [35]. After electroblotting, the membranes were air dried and blocked for $1 \mathrm{~h}$. After being washed in TBST (TBS/Tween $200.05 \%$ ), membranes were incubated for $1 \mathrm{~h}$ at room temperature in monoclonal antibody to SPARC (1:100 in TBST; Novocastra, Newcastle upon tyne, UK) and, after washing, in HRP-conjugated rabbit anti-mouse serum (1:40,000 dilution, Sigma). Immunoreactive bands were revealed using the Opti-4CN substrate (Bio-Rad, Segrate, Milan, Italy).

\section{Statistical analysis}

All tests were run in duplicate. Data from the two runs are expressed as means \pm SEM and were analyzed by ANOVA followed by the Student-Neumann-Keuls test. $P<0.05$ was considered significant.

\section{Results}

\section{Cell viability and proliferation}

The results for controls and Ukrain-treated human glioblastoma cells are presented in Fig. 1. The dose of $0.1 \mu \mathrm{mol} / \mathrm{l}$ Ukrain slightly affected cell proliferation. After $1 \mu \mathrm{mol} / \mathrm{l}$ Ukrain there was a tendency to less proliferation in treated cells, compared to controls, at all the intervals considered (reductions of 11, 26 and $14 \%$, respectively, after 24,48 and $72 \mathrm{~h}$ ). After the higher dose, $10 \mu \mathrm{mol} / \mathrm{l}$, proliferation was reduced at all the intervals of time, compared to controls (by 41,41 and $45 \%$ ). In particular, the high dose $(10 \mu \mathrm{mol} / \mathrm{l})$ significantly reduced cell proliferation after $48 \mathrm{~h}(P<0.05$ versus controls $)$ and $72 \mathrm{~h}(P<0.05$ versus controls and $1 \mu \mathrm{mol} / \mathrm{l}$ Ukrain).

\section{MMP-2 and SPARC gene expression}

Figure 2(a) shows MMP-2 gene expression. A slight tendency to lower MMP-2 mRNA levels was observed in glioblastoma cells 48 and $72 \mathrm{~h}$ after $10 \mu \mathrm{mol} / \mathrm{l}$ Ukrain (10 and $5 \%$, compared to controls, respectively). SPARC mRNA levels in controls and Ukrain-treated glioblastoma
Fig. 1

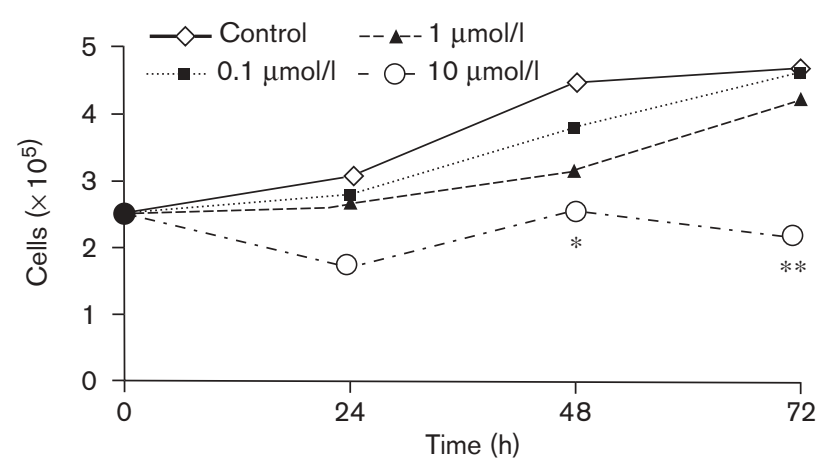

Time-dependent effect of Ukrain on cultured glioblastoma cell proliferation. Cells were plated in T-25 flasks (250000 cells/flask) and allowed to attach. Fresh medium containing $0.1,1$ and $10 \mu \mathrm{mol} / / \mathrm{Ukrain}$ was added, and cells were counted at the times indicated. Untreated glioblastoma cells were used as controls. Each time point represents the mean \pm SEM of duplicate samples. $* P<0.05$ versus control $(48 \mathrm{~h})$; $* * P<0.05$ versus control and $1 \mu \mathrm{mol} / \mathrm{l}(72 \mathrm{~h})$.

cells are shown in Fig. 2(b). Again, there was a tendency to downregulation 48 and $72 \mathrm{~h}$ after $10 \mu \mathrm{mol} / \mathrm{l}$ Ukrain (11 and $12 \%$ less than controls, respectively).

\section{SDS-zymography}

SDS-zymography analysis showed two lysis bands corresponding to pro-MMP-2 and -9 (Fig. 3a). Densitometric analysis of the pro-MMP-2 band indicated a $26 \%$ decrease of pro-MMP-2 levels $72 \mathrm{~h}$ after $10 \mu \mathrm{mol} / \mathrm{l}$ Ukrain and a $17 \%$ decrease for pro-MMP-9 at the same time, compared with controls (Fig. 3b and c).

\section{Western blot}

Densitometric analysis of immunoreactive bands indicated that SPARC protein levels tended to decrease in glioblastoma cells $48 \mathrm{~h}$ after $10 \mu \mathrm{mol} / \mathrm{l}$ Ukrain (20\% less than controls). At $72 \mathrm{~h}$, there were dose-dependent drops in protein levels $(13,22$ and $30 \%$, respectively, after 0.1 , 1 and $10 \mu \mathrm{mol} / \mathrm{l}$ Ukrain, compared with controls; $P$ ANOVA $=0.002)($ Fig. $4 \mathrm{a}$ and $\mathrm{b})$.

\section{Discussion}

The highly invasive phenotype of malignant gliomas means that the prognosis is poor, even using multidisciplinary approaches combining surgery, radiotherapy and chemotherapy [11]. Therefore, a better therapeutic strategy is still awaited for these brain tumors. In the search for new anti-tumoral agents over the past years, many plant extracts have been investigated. One is Ukrain, derived from the celandine plant. This is an anticancer compound with activity against a range of solid tumors, including those in the colon, rectum, breast, pancreas, bladder and ovary [6-10]. 
Fig. 2

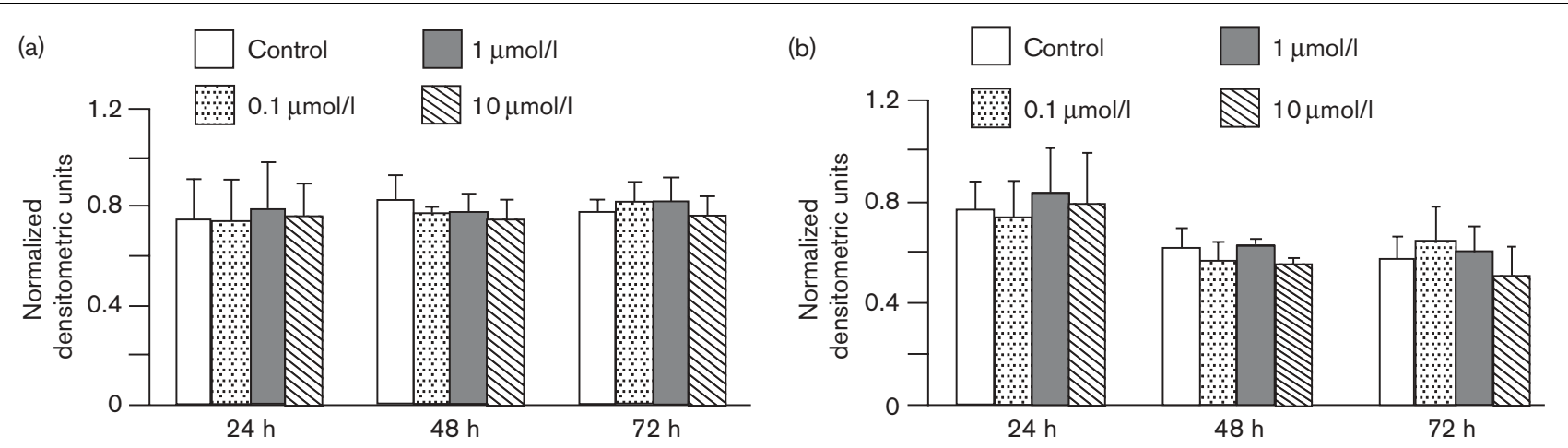

Bar graphs showing steady-state mRNA levels of MMP-2 (a) and SPARC (b) in cultured human glioblastoma cells at the times indicated. Changes in mRNA levels are expressed as normalized optical densities relative to GAPDH mRNA. Means \pm SEM.

Fig. 3

(a)
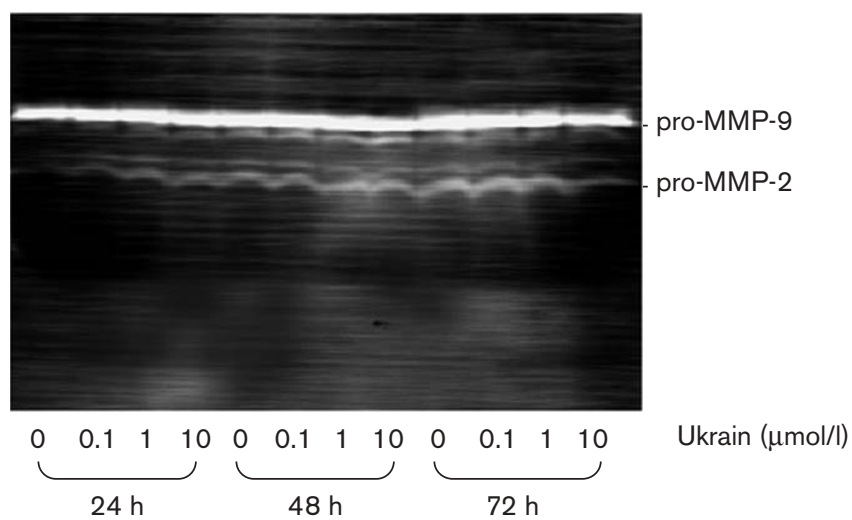

(b)

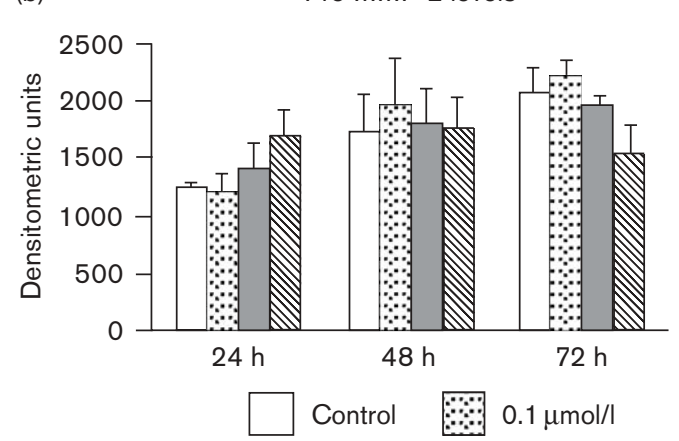

(c) Pro-MMP-9 levels

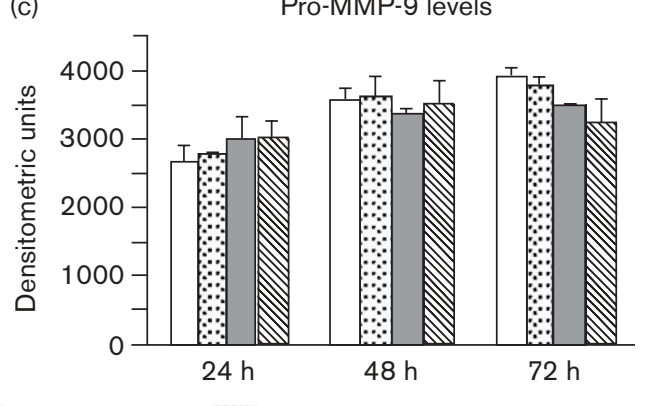

$1 \mu \mathrm{mol} / \mathrm{l}$
$10 \mu \mathrm{mol} / \mathrm{l}$

(a) Representative SDS-zymography showing two lysis bands consistent with pro-MMP-2 and -9. Glioblastoma supernatants were electrophoresed on 7.5\% gels. (b) Bar graphs showing pro-MMP-2 and (c) -9 levels after densitometric scanning of lysis bands. Means \pm SEM.

We employed three doses of Ukrain to investigate in vitro whether this drug has some effect on glioblastoma cell proliferation and on the expression of genes involved in the mechanisms leading to tumor invasion. Ukrain reduced glioblastoma cell proliferation 24,48 and $72 \mathrm{~h}$ after treatment. This pattern was dose dependent and 

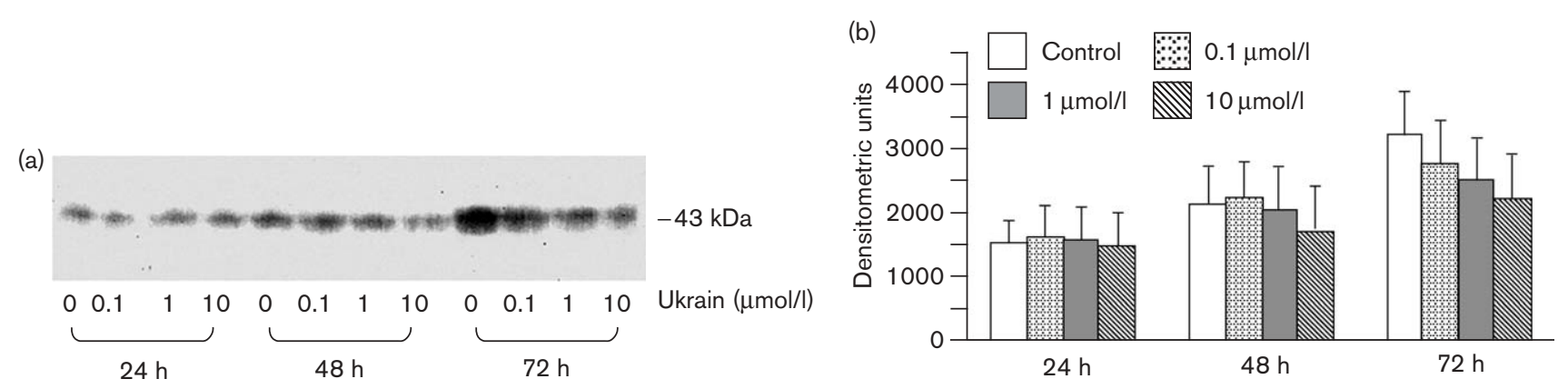

(a) Western blot analysis for SPARC protein in glioblastoma supernatants. The monoclonal antibody identifies a positive immunoreactive band in the 43-kDa region corresponding to SPARC. (b) Bar graphs showing SPARC protein levels after densitometric scanning of immunoreactive bands. Means \pm SEM.

proliferation appeared already to be affected by $1 \mu \mathrm{mol} / 1$ Ukrain, which lowered cell proliferation compared with controls. This effect was more evident after the $10 \mu \mathrm{mol} / \mathrm{l}$ dose, which elicited a significant decrease of cell proliferation. Interestingly, the proliferation curve of glioblastoma cells treated with $10 \mu \mathrm{mol} / \mathrm{l}$ Ukrain indicated that the number of cells remained the same at all times, compared to untreated cells, pointing to complete inhibition of cell proliferation and suggesting that the high dose had a cytostatic effect.

In accordance with previous findings, we speculate that the concentration-dependent effect of Ukrain on tumor cell viability very likely involves inhibition of DNA, RNA and protein synthesis [36], and possibly, as previously reported, also by an effect on the induction of apoptosis $[37,38]$.

The expression of genes and proteins involved in the ECM remodeling associated with tumor invasion showed that the two main determinants, MMP and SPARC, were differently targeted by Ukrain. MMP-2 and -9 are the gelatinases mainly involved in ECM remodeling, allowing tumor cells to break down basement membranes and diffuse into the surrounding tissues. Their expression also correlates with the progression and the degree of malignancy of gliomas [23,24].

Ukrain had no effect on MMP-2 mRNA levels. However, pro-MMP-2 and -9 showed a tendency to lower protein levels $72 \mathrm{~h}$ after the highest dose of the drug. These results suggest that the high dose of Ukrain slightly affects gelatinase expression at the protein level, although the difference between Ukrain-treated and control samples was not statistically meaningful.

SPARC is a matricellular protein required for interactions between cells and their extracellular environment and, on account of its counter-adhesive properties, it may have a functional role in tumor cell invasion of adjacent brain tissue. Since this protein is frequently overexpressed in gliomas, and its expression correlates with glioma invasion in vitro and in vivo [29,30], SPARC may be considered a marker of invading cells. This protein may possibly play a major role in the promotion of glioma cell invasion, as confirmed by evidence that human glioma cells engineered to overexpress SPARC adopt an invasive phenotype [31].

Another role for SPARC in the promotion of tumor progression has also recently been suggested [39] - it may facilitate tumor cell survival under the stressful conditions that surround the tumor, such as nutrient restriction, hypoxia and genomic instability. The expression of SPARC by gliomas induces cellular survival in serum-free conditions and the apoptotic rate of SPARCexpressing glioma cell lines is reduced compared to a control line. This might be a mechanism through which gliomas resist cell death [16]. SPARC, therefore, being involved in tumor invasion and resistance to apoptosis, may be an important target for the design of strategies for cancer therapy, especially to restrict glioma invasion.

Ukrain affects SPARC expression. SPARC mRNA levels were slightly reduced by the high dose, whereas at the protein level the drug had an evident dose-dependent effect, leading to downregulation of SPARC protein expression, although the difference between Ukraintreated and control samples was not significant. However, since patients receiving pharmacological anti-tumor therapy receive chronic treatment, protracted treatment with Ukrain might well have worthwhile activity against glioblastoma.

As a whole, our results suggest that Ukrain influences some major aspects of progression in human glioblastoma 
cells, such as cell proliferation and the expression of a pivotal protein in the mechanisms, leading to tumor cell invasion and survival. Thus, Ukrain may have some potential for the therapy of brain tumors, and could well also help extend our understanding of the mechanisms of this anti-tumor and chemopreventive potential.

\section{Acknowledgment}

We thank J.D. Baggott for language editing.

\section{References}

1 Kretmair H. Hypericum perforatum, St John's wort. Pharmazie 1950; 5:85-88.

2 Nowicky JW, Manolakis G, Meijer D, Vatanasspt V, Brzosko WJ. Ukrain both as an anti-cancer and immunoregulatory agent. Drug Exp Clin Res 1992; 28(Suppl):51-54

3 Jagiello-Woitowicz E, Kleinrok Z, Urbanska EM. Ukrain (NSC-631570) in experimental and clinical studies: a review. Drug Exp Clin Res 1998; 24:213-219.

4 Liepins A, Nowicky JW. Activation of spleen cell lytic activity by the alkaloid thiophosphoric acid derivative: Ukrain. Int J Immunopharmac 1992; 14:1437-1442.

5 Koshelnick Y, Moskvina E, Binder BR, Nowicky JW. Ukrain (NSC-631570) inhibits angiogenic differentiation of human endothelial cells in vitro. In: Abstracts of 17th International Cancer Congress, Brazil; 1998. pp. 91-95.

6 Susak YM, Zemskov VS, Yaremchuk OY, Kravchenco OB, Yatsyk IM, Korsh OB. Comparison of chemotherapy and X-ray therapy with Ukrain monotherapy for colorectal cancer. Drugs Exp Clin Res 1996; 22:115-122.

7 Uglianitsa KN, Nefyodov LI, Brzosko W. Evaluation of the efficacy of Ukrain in the treatment of breast cancer: clinical and laboratory studies. Drugs Exp Clin Res 1998; 24:231-239.

8 Uglianitsa KN, Nechiporenko NA, Nefyodov LI, Brzosko WJ. Ukrain therapy of stage T1NOMO bladder cancer patients. Drugs Exp Clin Res 1998; 24:227-230.

9 Zemskov V, Prokopchuk O, Susak Y, Zemskov S, Tkachenko O, Hodysh Y, et al. Efficacy of Ukrain in the treatment of pancreatic cancer. Langenbecks Arch 2002; 387:84-89.

10 Ernst E, Schmidt K. Ukrain - a new cancer cure? A systematic review of randomised clinical trials. BMC Cancer 2005; 5:69.

11 Kleihues P, Soylemezoglu F, Schauble B, Scheithauer BW, Burger PC. Histopathology, classification, and grading of gliomas. Glia 1995; 15:211-221.

12 Sehgal A. Molecular changes during the genesis of human gliomas. Semin Surg Oncol 1998; 14:3-12.

13 Daumas-Duport C, Scheithauer B, O'Fallon J, Kelly P. Grading of astrocytomas. A simple and reproducible method. Cancer 1988; 62:2152-65.

14 Shapiro WR. Current therapy for brain tumors. Arch Neurol 1999; 56:429-432.

15 McCawley LJ, Matrisian LM. Matrix metalloproteinases: multifunctional contributors to tumor progression. Mol Med Today 2000; 6:149-156.

16 Rao JR. Molecular mechanisms of glioma invasiveness: the role of proteases. Nat Rev Cancer 2003; 3:489-501.

17 Rempel SA, Golembieski WA, Fisher JL, Maille M, Nkeff A. SPARC modulates cell growth, attachment and migration of U87 glioma cells on brain extracellular matrix proteins. J Neurooncol 2001; 53:149-160.

18 Chintala SK, Tonn JC, Rao JS. Matrix metalloproteinases and their biological function in human gliomas. Int J Dev Neurosci 1999; 17:495-502.
19 Woessner FJ. Matrix metalloproteinases and their inhibitors in connective tissue remodeling. FASEB J 1991; 5:2145-2154.

20 Rooprai HK, McCormick D. Proteases and their inhibitors in human brain tumors: a review. Anticancer Res 1997; 17:4151-4162.

21 Stetler-Stevenson WG, Yu AE. Proteases in invasion: matrix metalloproteinases. Cancer Biol 2001; 11:143-152.

22 Vince GH, Wagner S, Pietsch T, Klein R, Goldbrunner RH, Rosen K, et al. Heterogeneous regional expression patterns of matrix metalloproteinases in human malignant gliomas. Int J Dev Neurosci 1999; 17:437-445.

23 Forsyth PA, Wong H, Laing TD, Rewcastle NB, Morris DG, Muzik H, et al. Gelatinase-A MMP-2, gelatinase-B MMP-9 and membrane type matrix metalloproteinase-1 MT1-MMP are involved in different aspects of the pathophysiology of malignant gliomas. Br J Cancer 1999; 79:1828-1835

24 Wang M, Wang T, Liu S, Yoshida D, Teramoto A. The expression of matrix metalloproteinase-2 and -9 in human gliomas of different pathological grades. Brain Tumor Pathol 2003; 20:65-72.

25 Bornstein $\mathrm{P}$, Sage EH. Matricellular proteins: extracellular modulators of cell function. Curr Opin Cell Biol 2002; 14:608-616.

26 Bradshaw AD, Sage EH. SPARC, a matricellular protein that functions in cellular differentiation and tissue response to injury. J Clin Invest 2001; 107:1049-1054.

27 Brekken RA, Sage EH. SPARC, a matricellular protein: at the crossroads of cell-matrix communication. Matrix Biol 2000; 19:569-580.

28 Tremble PM, Lane TF, Sage EH, Werb Z. SPARC, a secreted protein associated with morphogenesis and tissue remodeling, induces expression of metalloproteinases in fibroblasts through a novel extracellular matrixdependent pathway. J Cell Biol 1993; 121:1433-1444.

29 Golembieski WA, Ge S, Nelson K, Mikkelsen T, Rempel SA. Increased SPARC expression promotes U87 glioblastoma invasion in vitro. Int J Dev Neurosci 1999; 17:463-472.

30 Schultz C, Lemke N, Ge S, Golembieski WA, Rempel SA. Secreted protein acidic and rich in cysteine promotes glioma invasion and delays tumor growth in vivo. Cancer Res 2002; 62:6270-6277.

31 Vajkoczy P, Menger MD, Goldbrunner R, Ge S, Fong TAT, Vollmar B, et al. Targeting angiogenesis inhibits tumor infiltration and expression of the proinvasive protein SPARC. Int J Cancer 2000; 87:261-268.

32 Magnani I, Guerneri S, Pollo B, Cirenei N, Colombo BM, Broggi G, et al. Increasing complexity of the karyotype in 50 human gliomas. Cancer Genet Cytogenet 1994; 75:77-89.

33 Kleiner DE, Stetler-Stevenson WG. Quantitative zymography: detection of picogram quantities of gelatinases. Anal Biochem 1994; 218:325-329.

34 Laemmli UK. Cleavage of structural proteins during the assembly of the head of bacteriophage T4. Nature 1970; 227:680-685.

35 Burnette WM. 'Western blotting': electrophoretic transfer of proteins from sodium dodecyl sulfate-polyacrylamide gels to unmodified nitrocellulose and radiographic detection with antibody and radioiodinated protein A. Anal Biochem 1981; 112:195-203.

36 Nowicky JW, Hiesmayr W, Nowicky W, Liepins A. Influence of Ukrain on DNA, RNA and protein synthesis in malignant cells. Drugs Exp Clin Res 1996; 22:81-91.

37 Liepins A, Nowicky JW, Bustamante JO, Lam E. Induction of bimodal programmed cell death in malignant cells by the derivative Ukrain NSC631570. Drugs Exp Clin Res 1996; 22:73-79.

38 Roublevskaia IN, Polevoda BV, Ludlow JW, Haake AR. Induced $\mathrm{G}_{2} / \mathrm{M}$ arrest and apoptosis in human epidermoid carcinoma cell lines by semisynthetic drug Ukrain. Anticancer Res 2000; 20:3163-3167.

39 Shi Q, Bao S, Maxwell JA, Reese ED, Friedman HS, Bigner DD, et al. Secreted Protein Acidic, Rich in Cysteine, SPARC, mediates cellular survival of gliomas through AKT activation. J Biol Chem 2004; 279:52200-52209. 